Claves. Revista de Historia, Vol. $5, \mathrm{~N}^{\circ} 8$

Montevideo, enero - junio 2019

(pp. 235 - 260) ISSN 2393-6584

DOI: http://dx.doi.org/10.25032/crh.v5i8.10

\title{
Peregrinando entre cárceres: trajetórias de encarceramento de presos políticos comunistas na Era Vargas (décadas de 1930 e 1940)
}

Pilgrimage between prisons: imprisonment trajectories of leftwings political prisoners in the Vargas Era (1930s and 1940s)

Priscila Sobrinho de Oliveira

Pontifícia Universidade Católica do Rio de Janeiro, Brasil

Recibido: 26/02/2019

Aceptado: 09/05/2019

Resumo: Este artigo analisa as trajetórias de encarceramento de quatro presos políticos durante a Era Vargas (1930-1945), um recorte analítico das trajetórias de vida narradas nas seguintes autobiografias: Vida de um revolucionário, de Agildo Barata (1962); Memórias, de Gregório Bezerra (1979); Caminhos Percorridos (memórias de militância), de Heitor Ferreira Lima (1982); e Uma vida em seis tempos (memórias), de Leôncio Basbaum (1976). Neste corpus documental, há um padrão de experiência prisional: após serem presos, os sujeitos são encarcerados na Casa de Detenção e nas colônias penais de Fernando de Noronha e Ilha Grande. O objetivo é analisar a experiência nas prisões e nos navios convertidos em "cárceres em movimento" para o transporte dos presos.

Palavras-chave: preso político - Era Vargas - colônias penais

Abstract: This article analyzes the imprisonment trajectories of four political prisoners during the Vargas Era (1930-1945), which are an analytical cut of the life trajectories narrated in the following autobiographies: Vida de um revolucionário, by Agildo Barata (1962); Memórias, by Gregório Bezerra (1979); Caminhos Percorridos (memórias de militância), by Heitor Ferreira Lima (1982); and Uma vida em seis tempos (memórias), by Leôncio Basbaum (1976). In this documentary corpus, we identify a prison experience pattern: after being arrested, the subjects are imprisoned 
in the Casa de Detenção and in the penal colonies of Fernando de Noronha and Ilha Grande. The intention is to analyze the experience in these prisons and in the ships converted into "prisons in movement" for the transportation of prisoners.

Keywords: political prisoner - Vargas Era - penal colonies

\section{Introdução}

A Era Vargas (1930-1945) tem início quando Getúlio Vargas sobe ao poder através da Revolução de 1930, movimento armado que depôs o presidente Washington Luís e impediu que Julio Prestes, o presidente eleito, assumisse o mandato. Todo o longo governo Vargas seria, então, marcado por momentos de efervescência política assim como o que o levou à presidência. Logo no início, durante o Governo Provisório (1930-1934), Getúlio teve que lidar com a chamada Revolução Constitucionalista - uma guerra civil ocorrida em São Paulo entre julho e outubro de 1932, que teve como consequência a prisão e exílio de lideranças e militares paulistas derrotados, mas também consolidou a aliança entre Vargas e as Forças Armadas, assim como a convocação da Assembleia Constituinte para maio de $1933 .{ }^{1}$ Esse evento marca a primeira onda de prisões políticas; estas se intensificam conforme o governo se torna mais autoritário e promove repressão dos movimentos políticos divergentes.

Este artigo analisa o corpus documental composto pelas seguintes obras de memórias Vida de um revolucionário (1962); Memórias (1979, utilizamos aqui a segunda edição, de 2011); Caminhos Percorridos (memórias de militância) (1982); e Uma vida em seis tempos (memórias) (1976). Seus autores, Agildo Barata, Gregório Bezerra, Heitor Ferreira Lima e Leôncio Basbaum foram presos políticos durante a Era Vargas, em razão da militância comunista e compartilham trajetórias de prisão de padrão semelhante. Escritos no contexto da Ditadura Militar, podemos acreditar que estes autores, então já velhos militantes, escrevem para legar aos jovens militantes sua história de luta contra um governo autoritário. Configurando-se como um recorte analítico das trajetórias de vida dos autores, estas trajetórias prisionais são caracterizadas pela passagem por determinados cárceres, como a Casa de Detenção e

${ }^{1}$ SCHWARCZ, Lilia, STARLING, Heloísa. Brasil: Uma Biografia. São Paulo: Cia das Letras, 2015, p. 359-366. 
as colônias penais insulares localizadas em Fernando de Noronha, litoral de Pernambuco, e Ilha Grande, litoral do Rio de Janeiro.

Há toda uma produção de escritos, cartas, relatos de memórias, diários, entrevistas concedidas por presos durante ou sobre a experiência prisional. Estas fontes nos mostram o quanto aqueles homens mantiveram uma relação ativa com o mundo exterior, mesmo tendo a sua liberdade circunscrita ao espaço prisional. Carlos Aguirre, ${ }^{2}$ Lila Caimari, ${ }^{3}$ e Philippe Artières, ${ }^{4}$ são exemplos dessa historiografia que utiliza os relatos prisionais como fontes para reconstruir a experiência social da prisão. Artières afirma que a prisão, por vezes, constitui-se como uma “fábrica de textos", visto que a escrita é uma atividade à qual indivíduos presos frequentemente dedicam boa parte de seu tempo no cárcere. Dentro deste campo historiográfico que compreende a prisão desde a perspectiva dos presos, buscamos compreender como estes sujeitos construíram estratégias de sobrevivência em espaços de constante vigilância e liberdade cerceada e como narraram as relações que travaram entre si e com os outros que encontraram na prisão. Nossa hipótese é que a narrativa de prisão nos dá a ver a perspectiva dos presos sobre a vivência do cotidiano prisional e das relações que travam dentro do cárcere.

O artigo é composto por quatro partes. Na primeira, buscamos compreender os atos de prisão sofridos pelos autores que, apesar de se darem em dois contextos distintos da Era Vargas, 1932 e 1935, tem como consequência trajetórias de prisão semelhantes. Na segunda e quarta partes, buscamos compreender, respectivamente, a experiência nas Casas de Detenção, primeiro espaço prisional que ocupam os autores após serem presos e nas colônias penais insulares, último espaço prisional. Na terceira parte, analisamos os relatos das viagens de navios entre as prisões continentais e as colônias insulares que os autores vivem enquanto presos e que entendemos ser uma espécie de “cárcere em movimento".

Assim, a divisão do artigo se dá através das trajetórias de prisão dos autores conforme os espaços prisionais que ocupam e permite que estabeleçamos um diálogo

2AGUIRRE, C. The Criminals of Lima and their Worlds: The Prison Experience, 1850-1935. Durham: Duke University Press, 2005.

3 CAIMARI, L. Apenas un delincuente: crimen, castigo y cultura en la Argentina, 1880 - 1955. Buenos Aires: Siglo Veintiuno Editores.

4 ARTIÈRES, Philippe. Les Livres de Vies Coupables: autobiographies de criminels (1896-1909). Paris, Éditions Albin Michel, 2000. 
com uma história social das prisões no Brasil, assim como também com uma historiografia que busca pensar o mar e o navio como espaços de experiência social, tal como nos trabalhos de Linebaugh e Rediker e de Jaime Rodrigues. 5

\section{Os atos de prisão}

Apesar de não ter se envolvido com a movimentação em São Paulo, foi no contexto da repressão à dissidência durante a Revolução Constitucionalista que Heitor Ferreira Lima acabou sendo preso enquanto tentava seguir de Fortaleza, no Ceará, para Teresina, no Piauí em finais do ano de 1932. Ferreira Lima era secretário do PCB quando, em 1931, foi enviado para o Nordeste, com o objetivo de reforçar o trabalho de propaganda comunista nos estados da região. Ele já havia passado pelas capitais de Pernambuco e do Rio Grande do Norte quando foi preso na capital cearense, levado para a delegacia local e depois para a Casa de Detenção de Fortaleza, onde teve início sua trajetória de prisão. Depois, foi transferido dali para a Casa de Detenção do Rio de Janeiro e para a Colônia Correcional de Dois Rios, em Ilha Grande - de onde é libertado apenas em $1942 .^{6}$

Poucos meses antes da prisão de Lima, Leôncio Basbaum também havia sido preso em São Paulo - mostrando que a repressão política havia sido iniciada antes mesmo do conflito armado que caracterizou a Revolução Constitucionalista. Na ocasião, diversas categorias profissionais estavam em greve, exigindo melhores salários e direitos trabalhistas, mas também reivindicando que Vargas realizasse a Constituinte. O PCB, na ânsia de fazer parte do movimento, convocou uma reunião do seu Comitê de Greve no sindicato dos gráficos, localizado próximo à Praça da Sé. Importante membro do Bureau Político, Basbaum era encarregado de fazer um discurso que insuflasse os grevistas a expandir os protestos e reafirmasse o apoio do $\mathrm{PCB}$, mas mal teve chance de começar a falar quando policiais invadiram o salão e o levaram preso, junto com outros militantes e sindicalistas. Pouco tempo depois, foi

\footnotetext{
5 LINEBAUGH, Peter; REDIKER, Marcus. A hidra de muitas cabeças: marinheiros, escravos, plebeus e a história oculta do Atlântico revolucionário. São Paulo: Cia das Letras, 2008. RODRIGUES, Jaime. "Escravos, senhores e vida marítima no Atlântico: Portugal, África e América Portuguesa, c.1760 c.1875”. Almanack, Guarulhos, n. 5, p. 145-177, 2013.

6 LIMA, Heitor Ferreira. Caminhos percorridos (memórias de militância). São Paulo: editora Brasiliense, AEL, 1982, p. 146, 147.
} 
enviado para a Casa de Detenção do Rio de Janeiro e em seguida para a Colônia Correcional de Dois Rios, na Ilha Grande.7

Dessa forma, Basbaum e Lima foram vítimas da repressão ainda no Governo Provisório, quando Vargas governava por decretos e enfrentava forte oposição. Em 16 de julho de 1934, foi promulgada a nova Constituição e no dia seguinte Vargas foi eleito presidente da República através do voto indireto. Os outros dois autores, Gregório Bezerra e Agildo Barata, são presos no ano seguinte, 1935, por conta de suas atuações em posições de liderança nos levantes ocorridos em quartéis do Recife (capital de Pernambuco) e Rio de Janeiro, sob comando da Aliança Nacional Libertadora. Ambos também são os autores que passam mais tempo na prisão, pois são presos em 1935 e libertos apenas com a Lei de Anistia de 1945.

Diferente de Lima e Basbaum que ocupavam cargos importantes dentro da Direção do PCB, Gregório Bezerra e Agildo Barata não eram dirigentes naquele momento - seriam mais tarde, após a Anistia de 1945, mas desempenharam papéis importantes nos levantes comunistas de 1935. À Barata coube liderar a sublevação no $3^{\circ}$ Regimento de Infantaria do Exército, situado na Praia Vermelha, no bairro carioca da Urca. Ali, após horas de resistência armada contra as tropas do governo, os revolucionários capitularam e "saíram escoltados para a Av. Pasteur onde uma fila de ônibus da Light, solicitamente colocados à disposição do Governo" aguardava; dali foram transportados para a Casa de Detenção da Rua Frei Caneca e mais tarde para Fernando de Noronha. ${ }^{8}$

Já Bezerra tinha como tarefa liderar e deflagrar a revolução em Recife no dia 23 de novembro de 1935. O plano era "assaltar o quartel-general, a Secretaria de Segurança, o Palácio do Governo, a Central Telefônica e ocupar os pontos-chave da cidade”, porém, por um erro na ordem do comando, ele foi obrigado a iniciar o levante praticamente sozinho. A ordem emitida mandava pôr em prática o plano em um momento do dia em que os quartéis se encontravam esvaziados dos oficiais e soldados comprometidos com a causa. Tentando dar conta da ordem, o autor acabou entrando numa troca de tiros com dois oficiais, sendo alvejado pelas costas e recebendo um tiro na coxa. Ferido, tentou buscar sujeitos que aderissem ao levante e o ajudassem e

\footnotetext{
7 BASBAUM, Leôncio. Uma vida em seis tempos (memórias). São Paulo: Alfa-Ômega, 1978, p. 123-126. 8 BARATA, Agildo. Vida de um revolucionário (memórias). São Paulo: Alfa-Ômega, 1978, p. 300.
} 
acabou sendo levado ao pronto-socorro, onde recebeu voz de prisão. Por ser sargento do Exército, Gregório foi levado preso ao quartel general do Exército e transferido para a Casa de Detenção de Recife. Ali, foi mantido incomunicável até 1936, quando passou a sofrer interrogatórios sob tortura antes de ser enviado para Fernando de Noronha.

Os levantes de novembro de 1935 tiveram como efeito a prisão não só dos sujeitos que participaram diretamente, mas de muitos outros membros da ANL e do PCB e de simpatizantes através da Comissão de Repressão ao Comunismo, causando a contínua desmobilização da esquerda nos anos subsequentes. Esses homens foram enquadrados na Lei de Segurança Nacional e, quando não foram presos sem processo - caso de Lima e Basbaum - foram julgados sumariamente pelo Tribunal de Segurança Nacional superlotando prisões continentais e insulares. Além disso, foram um pretexto importante para a aprovação do estado de sítio e para o contínuo fechamento do regime, culminando na institucionalização da ditadura com o Golpe do Estado Novo em novembro de 1937 e suspensão da Constituição de 1934 e as eleições que estavam previstas para o ano de 1938.9

\section{Nas Casas de Detenção}

Após a prisão, as Casas de Detenção do Rio de Janeiro, Pernambuco, São Paulo e Ceará foram o destino carcerário dos nossos presos, onde ficaram detidos aguardando a transferência para uma das ilhas prisionais. Estes estabelecimentos datam do século XIX, momento em que as prisões estavam sendo pensadas como parte do projeto civilizador, pois substituiriam as penas de castigos corporais e públicos relacionadas à antiga ordem colonial.

Construída em 1856, a partir de um andar térreo da Casa de Correção da Corte, a Casa de Detenção do Distrito Federal tinha caráter provisório e, com o tempo, foi se tornando definitiva. Ambas as Casas eram situadas no mesmo endereço da rua Frei Caneca, tendo a prisão para correcionais sido a primeira do tipo criada no país em 1834, dentro do movimento transnacional de reforma e modernização das prisões em voga no século XIX, e inspirada no modelo da prisão norte-americana de Auburn, porém apenas parte do projeto foi construído antes que o orçamento se esgotasse.

9 SCHWARCZ, Lilia, STARLING, Heloísa. Ob.cit., p. 372-375. 
Logo surgiram outras Casas de Correção e Detenção nas principais capitais do Império. E, apesar do que dizia o Código Criminal de 1830 sobre as instituições serem destinadas à aplicação principalmente de penas de prisão com trabalho, logo a superlotação foi tamanha que o Império decretou que penas de tal natureza fossem cumpridas na colônia penal de Fernando de Noronha. Segundo Chazkel,10 "os nomes destas duas instituições [Casas de Detenção e Correção] resumem seus respectivos propósitos: uma desejava corrigir e a outra simplesmente deter”. Assim, as Casas de Detenção recebiam presos que estivessem detidos para averiguação ou que esperavam julgamento. Nas primeiras décadas da República, essas instituições passaram também a receber presos políticos provenientes da repressão aos movimentos anarquista e comunista e das inúmeras greves que começaram a eclodir a partir da década de 1910. A década de 1930 vê crescer a quantidade de prisões políticas que já vinham ocorrendo desde o início do século, sendo agora baseadas em uma legislação própria.

Levado com os outros presos políticos do $3^{\circ}$ Regimento de Infantaria em ônibus da Light para a Casa de Detenção do Rio de Janeiro, Agildo Barata registra sua impressão sobre o local: "este presídio era destinado a detentos da justiça comum e, assim, desde os primeiros dias de nossa prisão, a ditadura getulista evidenciava seus propósitos de relegar ao mais absoluto desprezo, qualquer respeito à nossa situação de presos políticos”. ${ }^{11} \mathrm{O}$ autor não apenas demonstra descontentamento por ser levado para aquela prisão, estigmatizada desde seus primeiros anos, mas por aquele ser um lugar destinado aos presos da justiça comum - com os quais ser misturado denotaria o desprezo estatal.

Dentre os presos comuns que encontra em sua passagem pela Casa de Detenção, Barata conhece um malandro carioca chamado de Meia-Noite, ${ }^{12}$ que teria se apresentado como um admirador e exigido do Diretor da prisão que o preso político fosse transferido para uma cela melhor quando ele havia sido posto em uma solitária. Aos olhos do preso político, Meia-Noite seria tão poderoso dentro da Detenção que desempenharia um papel de "superdiretor" da prisão. Além disso, denuncia a

\footnotetext{
10 CHAZKEL, Amy. "Uma perigosíssima lição: A Casa de Detenção do Rio de Janeiro na Primeira República”. Em: MAIA, C., NETO, F.S., COSTA, M., BRETAS, M. História das Prisões no Brasil. Rio de Janeiro, 2009, vol. 2, p. 10.

${ }^{11}$ BARATA, Agildo. Ob.cit. p. 303.

12 Uma nota no Jornal do Brasil poucos anos depois afirma que o malandro Meia-Noite morreu "justamente quando ele ia ensaiando os primeiros passos para a regeneração". Jornal do Brasil, 2 de setembro de 1937, "Meia Noite".
} 
corrupção da diretoria do presídio: segundo Barata o diretor da Casa de Detenção não só recebia dinheiro do malandro Meia-Noite como também teria outras formas corruptas de ganhar dinheiro, como o esquema de servir o almoço dos presos em um horário tardio de forma que pudesse cancelar o serviço do jantar, poupando os gastos com alimentação dos presidiários. ${ }^{13}$

Além de críticas à instituição prisional, podemos encontrar no relato de Barata conflitos entre os detentos e autoridades prisionais. Na única referência a mulheres em situação de prisão política que podemos encontrar no corpus documental analisado neste artigo, o autor relata o episódio em que uma companheira presa política se encontrava doente e os presos políticos se organizaram e exigiram que o presídio providenciasse um médico. Diante da reivindicação negada, os presos políticos enfrentaram os guardas e exigiram uma audiência:

"Forçamos a saída do pavilhão onde nos encontrávamos e fomos, mesmo empurrando os guardas que procuravam deter-nos, até o gabinete do diretor onde este, acovardado, se escondeu num W.C. privativo do diretor. Encontramos em seu lugar, um tal Pestana, vice-diretor, a quem obrigamos a telefonar, no momento, chamando um médico e só nos retiramos depois do médico vir entrando no presídio...”.14

O episódio mostra um embate entre os presos políticos, os guardas e a direção do presídio que teve como consequência o recolhimento de Barata e seus companheiros à solitária.

Todos os outros presos também registraram passagem pela Casa de Detenção do Rio de Janeiro em algum momento. Leôncio Basbaum chegou ali após transferência efetuada em vagões de trem de carga, vindo de São Paulo. Conta que, ao chegar ao Rio, os presos decidiram suspender a greve de fome que faziam há alguns dias desde a capital paulista e puderam saborear o café com pão que lhes foi servido, o que lhes “trouxe alma nova e o coração alegre". Porém, não demorou muito para que logo começassem a se organizar pois como militantes que eram, o dever da militância não poderia ser deixado de lado em nenhum momento. A prisão era convertida então em mais um espaço para socialização da militância:

13 BARATA, Agildo. Ob.cit. p. 309 e 214, respectivamente.

${ }_{14}$ BARATA, Agildo. Ob.cit. p. 316. 


\begin{abstract}
"Passado esse momento de reconforto, tratamos imediatamente de eleger uma nova direção do 'coletivo', composto de cinco pessoas, e a distribuir o tempo, marcando horas de discussão e estudos teóricos para os que quisessem: marxismo, situação brasileira, União Soviética, socialismo etc., eram temas de estudo e discussão. Análise da atuação do Partido, não era conveniente, pelo menos no momento."15
\end{abstract}

O "coletivo" era a forma como os presos políticos de esquerda se organizavam para manter a união e continuar realizando a militância mesmo dentro da prisão. Através da organização, os presos se posicionavam frente às autoridades prisionais e pleiteavam junto ao diretor da Casa de Detenção o que acreditavam ser de direito, como momentos ao ar livre, fornecimento de leite para os mais velhos e enfermos, talheres e colchões.

Para passar o tempo, os presos jogavam xadrez cujas peças confeccionavam com miolo de pão e cujo tabuleiro era um pedaço de cartolina riscado. Mesmo assim, "ao fim de dois meses de prisão, na mesma cela, sem ver a luz do sol, sem ter o que fazer, estávamos, na verdade, todos enervados”. O estado de exasperação se tornava mais intenso a cada dia, até que se tornou algo provavelmente entendido pelas autoridades prisionais como um motim. Os presos políticos, após terem a reivindicação de passar um tempo ao ar livre negada, teriam começado "a fazer barulho de marmita nas grades, acompanhado de gritos e cantos, do que os detentos se aproveitavam para fazer barulho também, o que transformou nossa galeria em um inferno de barulho". Como castigo para o protesto, o presídio suprimiu o leite para os idosos e enfermos e suspendeu o direito de visitas que haviam conquistado recentemente. Mas o movimento não parou por aí.

Tendo o pedido de conversar com o diretor da Casa de Detenção negado, vários presos teriam se lançado às tábuas que pregavam as janelas do presídio e as arrancado com as próprias mãos. $\mathrm{O}$ autor relata que:

\footnotetext{
"Logo compareceu a polícia militar, de armas embaladas, apontadas contra nós, com ameaças de fuzilamento sumário. Mas não nos intimidamos e começamos a cantar a Internacional e o hino nacional. Vendo que não nos intimidávamos, apareceu um recado
}

15 BASBAUM, Leôncio. Uma vida em seis tempos (memórias). São Paulo: Alfa-Ômega, 1976, p. 127. 
do Diretor dizendo que nomeássemos uma comissão para falar com ele. Foram indicados Grazzini, Morena e eu."16

Basbaum foi autorizado a conversar com o "Diretor em sua sala, devidamente guardada por dentro e por fora por soldados de armas embaladas, como se eu fosse capaz, mesmo desarmado, de tomar o poder, ou mesmo agredi-lo”. Dessa conversa, Basbaum diz ter recebido alguns xingamentos e a palavra do Diretor de que falaria com os seus superiores sobre as reivindicações. Apesar desse episódio ter sido seguido da estadia nas solitárias da Casa de Detenção, podemos questionar se a margem para negociação seria possível se Basbaum fosse um preso por crime dito comum ou se o movimento teria sido simplesmente resolvido com repressão pura e violenta.

Basbaum passou cerca de um mês em uma das cinco "celas de castigo" que "tinham mais ou menos um metro e oitenta de comprimento por um de largura; toda em cimento, fazia um frio e uma umidade difícil de suportar”. O porão do presídio onde ficavam estas celas é descrito pelo autor como uma área "quase totalmente escura, alumiada por uma pequena lâmpada presa ao teto, que de quase nada servia. [...] A luz mais forte vinha de três pequenas aberturas de mais ou menos dez por dez centímetros, quase no teto, de uns dois metros de altura". Depois, ao retornar à cela dos presos políticos, deparou-se com um clima que definiu como "o pior possível", "pois estavam quase todos brigados entre si, formando pequenos grupos. Todos temiam a transferência para a Ilha Grande, coisa que lhes parecia certa, conforme haviam sido avisados por um preso." A informação do preso não identificado procedia; eles seriam transferidos para a Ilha Grande nos dias seguintes. ${ }^{17}$

Heitor Ferreira Lima também esteve preso na Casa de Detenção da Capital Federal, mas por pouco tempo enquanto esperava sua transferência para a Colônia Correcional de Dois Rios. Antes, experimentou o encarceramento na Casa de Detenção cearense - também referida como Cadeia Pública, construída entre 1851 e $1866 .{ }^{18} \mathrm{Ali}$, ocupou uma cela do andar térreo, onde encontrava-se a galeria de presos comuns.

Nos primeiros dias de outubro, o autor teria sido despertado no meio da noite, recebido ordem de arrumar suas coisas e levado ao porto, onde o colocaram em um

\footnotetext{
16 BASBAUM, Leôncio. Ob.cit. p. 128 e 129.

17 BASBAUM, Leôncio. Ob.cit. p. 130, 131.

${ }^{18}$ FILHO, Porfírio de Lima. No tempo dos Látegos e dos Grilhões: memória sobre a Cadeia Pública de Fortaleza (1931). Fortaleza, Arquivo Público do Estado do Ceará, 2013.
} 
navio que faria a sua transferência para o Rio de Janeiro. Na então capital federal, o autor foi levado primeiro para a Polícia Central, na Rua da Relação, onde passou alguns dias antes de ser levado para a Casa de Detenção. Na prisão da Rua Frei Caneca, foi posto em um cubículo junto com alguns presos políticos; logo seriam transferidos para a Colônia Correcional de Dois Rios, em Ilha Grande, litoral do Rio de Janeiro - onde encontraria outros presos políticos, inclusive Leôncio Basbaum. ${ }^{19}$

Quanto à Gregório Bezerra, seu primeiro destino carcerário foi a Casa de Detenção da cidade de Recife, presídio que data também do século XIX. Sua construção, aprovada pela Assembleia Legislativa pernambucana em 1848, urgia para que substituísse a Cadeia da cidade, que remetia ao período colonial e que não dava conta dos presos provenientes da violência e criminalidade crescente de uma grande cidade do Império do Brasil. ${ }^{20}$

Diferente dos outros autores que não relatam ter sofrido tortura, Gregório Bezerra conta que, enquanto esteve na Casa de Detenção, foi retirado algumas vezes no meio da noite e levado à Secretaria de Segurança Pública de Recife, onde era interrogado sob tortura. Segundo o autor, em 1935 "só houve espancamentos nos atos de prisão, mas não houve tortura. Estas começaram, violenta e barbaramente, em fevereiro [de 1936], principalmente depois da prisão de Luiz Carlos Prestes, no Rio.” ${ }^{11}$

O autor conta sobre ter se tornado amigo de um carcereiro que definiu como um rapaz jovem e de boa aparência, mas que havia sido "intoxicado pela propaganda contra mim e contra os comunistas em geral”. Esse rapaz exercia a tarefa de vigilância com extremo afinco:

\footnotetext{
"quando encontrava uma ponta de cigarro defronte de minha grade ou nas vizinhanças de minha cela, abria e esfarinhava o fumo para ver se havia algo escrito. Quando me levava ao banheiro, fazia-me esperá-lo à porta, distorcia o chuveiro, metia o dedo no interior do cano de água para ver se tinha algo escrito; levantava o ralo do esgoto do
}

19 LIMA, Heitor Ferreira. Caminhos Percorridos (memórias de militância). São Paulo: Brasiliense e AEL, 1982, p. 160.

${ }^{20}$ NETO, Flávio de Sá C.A. "Da cadeia à Detenção: reforma prisional no Recife em meados do século XIX”. Em: MAIA, C., NETO, F.S., COSTA, M., BRETAS, M. História das Prisões no Brasil. Rio de Janeiro, 2009, vol. 2.

${ }^{21}$ BEZERRA, Gregório. Memórias. São Paulo: Boitempo, 2011, p. 247. 
banheiro, arregaçava a manga da túnica e atolava a mão no esgoto. Feitas estas operações, mandava-me entrar e ficava esperando para levar-me de volta ao cubículo.”22

Os presos políticos comunistas eram submetidos à ostensiva vigilância, mas Bezerra em especial era visto como elemento extremamente perigoso por ter desempenhado papel central no levante de novembro de 1935. Apesar disso, Bezerra decide tentar um contato amistoso com o guarda no dia em que o percebe andando nervosamente de um lado para outro e resolve lhe perguntar o que incomodava. Sabendo então que a razão do incômodo era o filho doente e a falta de dinheiro para levá-lo ao médico, Bezerra afirma ter entregue ao carcereiro os cinquenta mil-réis que tinha no bolso, afirmando que não estava dando o dinheiro ao carcereiro, mas ao seu filho doente e ainda teria lhe indicado "um médico especialista em doença infantil, o dr. João Tavares”. ${ }^{23}$ Disso, teria surgido uma amizade entre eles, resultando inclusive em conversas sobre o que era ser comunista, sugestões de leituras e posterior filiação do rapaz ao $\mathrm{PCB}$.

Como estratégias para burlar a incomunicabilidade e vigilância às quais estavam submetidos, Bezerra afirma que os presos políticos criaram várias formas de se comunicar dentro do presídio:

\begin{abstract}
"Utilizávamos os dedos da mão para fazer as letras do alfabeto. Como as portas das celas eram fechadas, além das grades, com as portas de madeira, só podíamos nos comunicar quando um companheiro de uma cela subia à janela que ficava ao alto e transmitia os sinais para outro companheiro, também postado em sua janela.”24
\end{abstract}

Com a saúde precária por conta das torturas, Gregório não conseguia subir a janela de sua cela, mas nem por isso ficava de fora do sistema de comunicação. Ele afirma que "o cabo Siqueira, que estava numa cela ao lado da minha, foi encarregado de me transmitir as mensagens, o que fazia através da parede, usando código morse.”

Descoberta essa forma de comunicação pouco tempo depois, seria substituída pelo que Bezerra se referiu por "merdafone": um sistema de comunicação no qual os presos transmitiam mensagens através dos vasos sanitários (com a água esvaziada).

22 BEZERRA, Gregório. Ob.cit. p. 252.

${ }_{23}$ Sobre o dinheiro que Gregório possuía, o autor afirma que havia sido enviado por sua esposa de maneira bem peculiar - atado com barbante a uma pedra que foi arremessada da rua para dentro de sua cela, o dinheiro acompanhava um bilhete dando notícias de que sua família se encontrava bem.

24 BEZERRA, Gregório. Ob.cit. p. 254. 
Segundo Gregório, era um meio de comunicação "muito eficiente", porém tinha o inconveniente de que o esgoto da Casa de Detenção vazava para o Rio Capibaribe, fazendo com que subissem gases fortes do manguezal quando era tempo de maré alta e causando intoxicação nos presos.

Como alternativa ao "merdafone", os presos tentaram domesticar baratas, por falta do que fazer e por ainda ter o problema de comunicação entre os presos para resolver:

\begin{abstract}
"Fizemos uma grande experiência. Pegamos uma grande barata, amarramos nela uma linha preta e exercitamo-la da seguinte forma: soltamo-la e deixamos que seguisse seu curso natural. Procurou esconder-se. Puxamo-la a ré. Não gostando de ser arrastada, seguia para a frente e, depois, à esquerda. Fizemos isso várias vezes. E, cada vez que a soltávamos e a arrastávamos, ela ia mais longe e assim, aprendeu a virar para a esquerda e para a direita, conforme a nossa vontade. Podíamos fazê-la entrar na porta vizinha à nossa cela. [...] Estava resolvido nosso problema de comunicação interna, com todos os companheiros da Casa de Detenção do Recife.”25
\end{abstract}

Não temos como saber se o problema de comunicação entre os presos foi resolvido com vasos sanitários ou domesticação de baratas, mas podemos compreender o relato como uma construção de uma memória da prisão política onde, apesar do cárcere, parecia não haver obstáculos que os comunistas não conseguissem ultrapassar para exercer sua liberdade e militância. Há um tom de heroísmo que tenta mostrar que os comunistas eram homens tão extraordinários que a prisão não era capaz de detê-los em quase nada.

O tempo que Gregório Bezerra passou na Casa de Detenção de Recife foi o início dos dez anos que passaria privado de liberdade. Mais tarde, tanto Bezerra quanto os outros presos políticos seriam transferidos para alguma das duas ilhas prisionais. Essa transferência se deu em navios e é sobre essas viagens feitas enquanto presos a caminho das colônias penais que tratamos a seguir.

\title{
Nos navios: o cárcere em movimento
}

A passagem pela Casa de Detenção antecedia a transferência para uma das ilhas prisionais, realizada em navios em situação extremamente precária. Ao ser embarcado

\footnotetext{
25 BEZERRA, Gregório. Ob.cit. p. 259.
} 
no navio que o levaria de Fortaleza para o Rio de Janeiro, Heitor Ferreira Lima foi encerrado em um cubículo estreito, “com rolos de toldos até a metade, de modo que só podia ficar sentado ou deitado incomodamente" onde "reinava escuridão completa; quando acendia a luz, era ela tão forte que me ofuscava a vista"; ali "havia uma faixa de metal amarelo de um palmo mais ou menos de largura, cheia de buracos redondos" que funcionava como única entrada de ar e que dava para o camarote dos foguistas do navio. ${ }^{26}$

Quando necessitava usar o banheiro, precisava comunicar aos foguistas, que em seguida avisavam ao cabo da guarda, este ao sargento do dia e em seguida ao oficial do dia - que concedia a autorização. Porém, às vezes a espera era prolongada: "Caso estivesse ele [o oficial do dia] jogando, minha espera era maior por não gostar de ser incomodado em tais ocasiões”. Sobre a alimentação no navio, Lima conta que:

\footnotetext{
"De manhã cedo, sem lavar o rosto ou sequer passar água na boca, tomava um café horroroso, numa caneca enferrujada. As refeições eram trazidas em pratos de alguidar que mostravam pedaços enferrujados também, com gosto tão esquisito que não parecia comida." 27
}

No caminho para o Rio de Janeiro, o navio atracou no porto de Natal, demorando-se um pouco ali enquanto era abastecido. Heitor Ferreira Lima aproveitou a ocasião para enviar um bilhete à "cooperativa" dos sapateiros local, pedindo dinheiro e recebendo de volta vinte mil-réis. As aspas são do próprio autor, o que é significativo por denotar que o órgão não funcionaria apenas tal como o esperado, mas que seus membros seriam ligados ao PCB.

No Rio, o autor passaria novamente pela experiência de deslocamento marítimo enquanto preso, porém por poucas horas a caminho da Ilha Grande. A viagem foi realizada no porão de um pequeno navio, em cujo centro havia um monte de pedras de carvão. Ali, os presos especulavam a respeito do provável destino: "Clevelândia, Fernando de Noronha, Dois Rios?” E, em tom de crítica, diz que atrás do monte de carvão "teve início a pederastia" entre os presos comuns - prática sexual entre indivíduos do mesmo sexo frequentemente criticada pelos presos políticos em suas memórias. Pela manhã, com o navio chegando à Dois Rios, os presos estariam com

\footnotetext{
${ }^{26}$ LIMA, Heitor Ferreira. Ob.cit. p. 160.

${ }_{27}$ BEZERRA, Gregório. Ob.cit. p. 161.
} 
"roupas e rostos manchados de preto, como se estivéssemos mascarados" por causa do carvão e que ao subir o convés para desembarcar, eles se depararam com uma "paisagem deslumbrante, lembrando uma aquarela". ${ }^{28}$

Pouco antes de Lima, Basbaum teria vivido a mesma viagem de navio. Ele e os presos políticos foram despertados de madrugada com ordens de arrumar suas roupas e foram levados para o cais do porto e embarcados "em um navio relativamente grande para tão curta viagem". O navio que os levaria era o "Anibal Benevolo, um velho cargueiro do Loide [sic], ${ }^{29}$ com o qual não nos atreveríamos, em condições normais, a ir a Niterói”. $3^{\circ}$ E ele se espanta pela precariedade da embarcação e excessivo aparato de segurança: "Era apenas o navio, na sua estrutura de ferro, com meia dúzia de tripulantes para conseguir que o navio andasse sem rebentar as caldeiras, e uns cem soldados armados, espalhados pelo convés." Ao anoitecer, foram todos dormir "arrumando, onde era possível, um lugar para se deitar, sempre com um olho vivo para os vagabundos", referindo-se aos presos comuns que também eram transferidos. ${ }^{31}$

Referências aos presos comuns como vagabundos, pederastas e mesmo "escória da humanidade" denotam preconceito, estigma e afastamento entre os indivíduos segundo a categoria de crime na qual eram condenados. Podemos considerar que os presos comunistas enxergavam os presos comuns como parte do lumpemproletariado, um estrato social inferior ao proletariado, formado pelos indivíduos com as condições materiais de existência mais precárias, como ladrões, prostitutas e mendigos diferente do carcereiro de Bezerra que, apesar de intoxicado pelo anticomunismo, era um trabalhador e poderia ser ganho para a causa comunista. ${ }^{2}$

Por sua vez, Gregório Bezerra afirma que os presos da Casa de Detenção foram transferidos em abril de 1939 para Fernando de Noronha, onde já se encontravam presos políticos enviados do Distrito Federal. A transferência se deu em meio a um

\footnotetext{
${ }^{28}$ BEZERRA, Gregório. Ob.cit. p. 164.

$29 \mathrm{O}$ autor provavelmente se refere à Companhia de Navegação Lloyd Brasileiro.

30 Niterói é uma cidade vizinha à cidade do Rio de Janeiro, também localizada na Baía de Guanabara, cuja travessia de barco leva cerca de 20 minutos.

${ }^{31}$ BASBAUM, Leôncio. Ob.cit. p. 131, 132.

32 Marx via a classe trabalhadora como uma unidade, o proletariado, e aos mendigos, criminosos e prostitutas como lumpemproletariado, um estrato social de trabalhadores precarizados que inspirava desconfiança pois suas condições vida "preparam-na bem mais para o papel de instrumento subornado de intriga reacionária". Ver: VAN DER LINDEM, Marcel. "O Conceito Marxiano de Proletariado: uma crítica”. Em: Sociologia \& Antropologia. Rio de Janeiro, v.o6.o1: 87- 110, abril de 2016.
} 
aparato bélico que o autor define como notável montado "desde a Casa de Detenção até o cais do porto, onde se achava à nossa espera o navio Rodrigues Alves. Saímos da Casa de Detenção do Recife em turmas de sessenta companheiros.”

No navio, o oficial da polícia que os comandava havia dado ordem para que ficassem no porão até a saída da barra e só então poderiam subir ao convés, com a condição de que se comportassem bem. Mais tarde, no convés "tudo correu muito bem até cerca das onze horas da noite, quando caiu uma chuvarada grossa" e os presos correram para se abrigar. Diante da correria dos presos políticos que fugiam da chuva,

"o capitão que comandava a escolta tomou o fato como uma desordem ou um princípio de revolta e ordenou à sua força que carregasse os fuzis e colocasse as metralhadoras em posição de tiro contra nós: uma turma de soldados, de baioneta calada, fez-nos voltar ao porão do navio."33

No porão, muitos presos teriam começado a passar mal, pois "o calor era desesperador; a falta de ar, completa. Não havia a mínima ventilação.” Ali, como nos navios que transportaram Leôncio Basbaum e Heitor Ferreira Lima para Ilha Grande, também não havia sanitários, o que transformava o ambiente claustrofóbico também em insalubre. Nesse contexto, os presos protestaram, pedindo ajuda ao médico de bordo e teriam recebido como resposta a permissão de manter o porão aberto mas com soldados apontando armas para intimidar os presos. Bezerra afirma que, no meio dessa tensão, os presos ofereceram os seus peitos aos fuzis e conseguiram, negociando aos poucos, retornar ao convés. A viagem teria prosseguido assim, com presos e soldados alertas uns com os outros e, a primeira coisa que teriam feito os presos políticos ao desembarcar na praia de Santo Antônio, em Fernando de Noronha, foi receber as boasvindas de companheiros de militância enviados do Rio de Janeiro e tomar banho de mar. Ao todo, cerca de duzentos homens ligados à Aliança Nacional Libertadora cumpriram pena em Fernando de Noronha.

\section{O cárcere final: as colônias penais insulares}

Após passagem pelas Casas de Detenção e do deslocamento marítimo em navios precários, os presos políticos chegavam às colônias penais de Fernando de Noronha $\mathrm{e}$ Ilha Grande, cárceres onde passariam o tempo final de suas penas.

\footnotetext{
33 BEZERRA, Gregório. Ob.cit. p. 274, 275.
} 
Há indícios de que desde o século XVII degredados eram transportados à Fernando de Noronha, porém o início da longa história de ocupação penal do arquipélago se dá em 1737 quando os primeiros sentenciados militares, desterrados e condenados a penas de galés foram enviados como mão-de-obra para construção de fortalezas - uma reação à ocupação daquela região por holandeses e franceses. 34 Já o regime civil do presídio começou oficialmente apenas em 1833, com o decreto imperial que definiu que o cumprimento de penas de galés perpétuas ou temporárias impostas aos condenados por fabricação de moeda falsa deveria ser realizado na ilha-prisão. 35 Assim, tem início o processo que torna a ilha uma prisão central para o Brasil Imperial, afinal, na prática, acabou se tornando uma espécie de depósito de condenados de todos os tipos, recebendo também militares e escravos. ${ }^{36}$

O envio de novos sentenciados para Noronha foi proibido em 1894, por conta do esvaziamento da população de presos durante a Guerra do Paraguai nos anos anteriores. A prisão foi perdendo importância e em 1897 foi fechada, sendo seu território integrado ao estado de Pernambuco, que a utilizou como prisão ao longo da Primeira República. Na década de 1930, com o envio dos presos políticos que lotavam os cárceres continentais, Vargas sancionou um decreto-lei que transformou a ilhaprisão em Colônia Agrícola de Fernando de Noronha e devolveu a jurisdição ao Governo Federal, destinando-a "à concentração e trabalho de indivíduos reputados perigosos à ordem pública, ou suspeitos de atividades extremistas”.37

Agildo Barata e Gregório Bezerra, julgados segundo a Lei de Segurança Nacional de 1935 que criminalizava determinadas ações e militâncias políticas, eram considerados como "indivíduos reputados perigosos à ordem pública" e foram enviados ao arquipélago. Bezerra afirma que, após o desembarque em Noronha, “nós, com os demais companheiros, fomos para o alojamento central dos presos políticos aliancistas." Explica que havia um "alojamento central dos aliancistas porque havia

34 O missionário capuchinho Claude d'Abbeville narra o encontro com alguns desterrados - um português e dezoito índios que viviam na ilha por volta de 1612 no livro "História da missão dos padres capuchinhos na ilha do Maranhão e suas circunvizinhanças", publicado em 1614.

35 Lei ${ }^{0} 52$ de 3 de outubro de 1833 , definiu Fernando de Noronha como local para o cumprimento das sentenças dos condenados por fabricação, introdução e falsificação de notas, cautelas, cédulas e papéis fiduciários, determinando a aplicação da pena de galés, isto é, trabalhos públicos forçados.

${ }_{36} 6$ COSTA, Marcos Paulo Pedrosa. O caos ressurgirá da ordem: Fernando de Noronha e a reforma prisional no Império. São Paulo: IBCCRIM, 2009.

37 Decreto-Lei $\mathrm{n}^{0} \quad 640$ de 22 de agosto de 1938. Disponível em: http://www2.camara.leg.br/legin/fed/declei/1930-1939/decreto-lei-640-22-agosto-1938-350872publicacaooriginal-1-pe.html. Acessado pela última vez em 06 de fevereiro de 2019. 
também um alojamento central para os presos integralistas [cerca de 100 integralistas foram enviados para Noronha em 1937] que também estavam na ilha", 38 demonstrando a existência de uma separação entre os presos políticos baseada na polarização política e ideológica. 39

Nesta polarização também era baseada a organização das atividades e tarefas do cotidiano prisional. Mário Magalhães (2012), autor da biografia de Carlos Marighella, que também foi preso político em Fernando de Noronha, afirma que:

\begin{abstract}
"Sem considerar os minoritários presos comuns mantidos para prestar serviços à administração, os condenados se apartavam em dois grupos: por volta de noventa integralistas e 180 militantes de esquerda, quase todos da extinta ANL, com hegemonia comunista. Não se misturavam: camisas-verdes se acomodavam num prédio, aliancistas em outros - no alojamento maior, em duas edificações médias também de alvenaria e em casas nas quais cabia meia dúzia de pessoas. As casinhas se erguiam com pedras, cobriam-se de palha de coco e tinham o chão de terra." 40
\end{abstract}

Em quase duzentos anos de existência a colônia penal sempre teve "por paredes o mar, e a própria ilha se constituía como prisão. Não existia um presídio enquanto edifício, com celas, grades e muros", como afirma Costa ${ }^{41}$ e desde as primeiras construções foi utilizada a mão-de-obra de condenados. No século XIX, as construções do presídio eram reunidas na vila dos Remédios: em volta de duas praças concentravam-se as casas de funcionários, o armazém, enfermaria, hospital, escola e a Igreja de Nossa Senhora dos Remédios, além do prédio chamado Aldeia, com espaço para poucos presos.

${ }^{38}$ BEZERRA, Gregório. Ob.cit. p. 275, 276.

39 Os integralistas eram membros e militantes da Ação Integralista Brasileira, um partido político de massas inspirado no fascismo italiano. Muitos integralistas foram presos com base na Lei de Segurança Nacional por conta de episódios ocorridos em março e maio de 1937. O primeiro foi um levante em quartéis da Marinha e o segundo foi uma tentativa de tomada do Palácio Guanabara, residência do Presidente da República à época, e assaltos às residências de líderes políticos ligados à Vargas, com objetivo de tirá-lo do poder. Relatórios "Intentona integralista de 11 de Março de 1938" e "Movimento integralista - 11 de maio de 1938". APERJ, fundo polícia política, setor integralismo, pasta 5, dossiê 1, folhas 706.

$4^{\circ}$ MAGALHÃES, Mário. Marighella, o guerrilheiro que incendiou o mundo. São Paulo: Cia das Letras, 2012, p. 32.

${ }^{41}$ COSTA, Marcos Paulo Pedrosa. "Fernando e o mundo - o Presídio de Fernando de Noronha no século XIX”. Em: BRETAS, Marcos, COSTA, Marcos, MAIA, Clarissa, NETO, Flávio de Sá. História das prisões no Brasil. Rio de Janeiro: Rocco, 2009. p. 138, 139. 
Historicamente, o trabalho coercitivo fora parte central do funcionamento da colônia penal de Fernando de Noronha. Porém, não era dessa forma que Bezerra compreendia, como podemos ver no seguinte trecho:

\footnotetext{
“Tínhamos, através do coletivo, uma política de colaboração com a diretoria do presídio: fazíamos o descarregamento e o carregamento dos navios, quando chegavam e saíam, e armazenávamos as mercadorias. Fornecíamos verduras a todas as famílias da ilha, ao hospital, ao destacamento policial e a todos os que estavam doentes, inclusive aos integralistas. Em troca, a diretoria nos fornecia os instrumentos de trabalho necessários." 42
}

Gregório Bezerra se refere às atividades laborais realizadas pelos presos políticos como fruto de uma "política de colaboração com a diretoria", na qual esta forneceria instrumentos de trabalho para que, em troca, eles trabalhassem para o presídio. Contudo, dificilmente haveria alguma margem de negociação sobre a realização de tarefas laborais se o regime do trabalho era parte central daquela experiência prisional. Todos os presos, assim que desembarcavam na ilha, eram fichados pela direção da prisão e alocados em alguma das companhias de trabalho encarregadas de tarefas como agricultura, pesca, construção43. Bezerra continua dizendo que tinham também permissão para realizar pesca, cultivar vegetais e frutas e ainda tinham um aviário, como se fossem atividades permitidas apenas a eles por serem presos políticos, mas eram as atividades cotidianas nas quais todos os presos, pelo menos desde o século XIX, deveriam realizar ou não teriam com o que se alimentar pois a provisão enviada do continente era insuficiente para toda a população prisional.

Logo Bezerra se veria longe de Noronha pois “do fim de 1941 para o início de 1942, [...] começaram a surgir boatos de que o arquipélago de Fernando de Noronha seria transformado em base militar”, o que de fato ocorreu quando da ocasião da entrada do Brasil na II Guerra Mundial.

\footnotetext{
42 BEZERRA, Gregório. Ob.cit. p. 476.

43 Arquivo Público Estadual Jordão Emerenciano (APEJE). Fundo Fernando de Noronha (FN), o01.519, 001.520, 001.521, Fichas de Presidiários 1927-1945.
} 
"No início de 1942, o general Mascarenhas de Morais veio verificar a situação estratégica da ilha e, poucos meses depois, nós fomos transferidos para a Ilha Grande, no Estado do Rio de Janeiro, ficando alojados no presídio político da colônia de Dois Rios”.44

Bezerra registrou suas impressões sobre Ilha Grande, comparando-a com a colônia penal anterior: "Quanto às vantagens da Ilha Grande sobre Fernando de Noronha, foram enormes". Fernando de Noronha, apesar dos "excelentes cajus, mamões deliciosos, pinhas [...], bananas e muito peixe”, teria uma água "ruim e poluída, [que] provocava-nos uma disenteria constante" e uma "nuvem de mosquitos, que não deixava ninguém dormir sossegado”. Reclama também que a correspondência "além de demorada, era severamente censurada" e os presos não teriam como receber visitas. Na Ilha Grande, os presos teriam acesso a água de excelente qualidade e eles podiam receber visitas, afinal a ilha tinha acesso mais fácil ao continente. E relaciona o fim da Segunda Guerra Mundial com o afrouxamento da vigilância: "à medida que os fascistas iam sendo esmagados nos campos de batalha, íamos tomando conta da praia, sem o acompanhamento dos guardas”. Em Ilha Grande tinham acesso à jornais e rádio levados pelos visitantes aos parentes encarcerados. 45

Diferente de Fernando de Noronha, que tinha já um longo passado penal quando os presos políticos do regime Vargas lá desembarcaram, a Ilha Grande só começou a funcionar como um presídio militar a partir de 1894, quando foi transformado o Lazareto que lá existia desde a década anterior. A construção era fruto de um conjunto de iniciativas que, desde meados do século XIX, buscavam expandir o controle preciso sob os indivíduos e seus movimentos. No fim de 1894, a Colônia Correcional de Dois Rios foi criada, a partir da fazenda de mesmo nome, que servia de apoio ao Lazareto. Nas primeiras décadas do século XX, a Colônia passa a receber cada vez mais presos acusados de contravenções, enquanto que o Lazareto passa a ser utilizado como prisão militar para os presos provenientes da repressão dos movimentos tenentistas em 1922 e 1924. Mais tarde ambas as construções recebem os presos da Revolução Constitucionalista de 1932 e dos levantes comunistas de 1935. Os dados não são assertivos, mas é possível afirmar que a ilha recebe cerca de

\footnotetext{
44 BEZERRA, Gregório. Ob.cit. p. 276 e 289.
}

45 BEZERRA, Gregório. Ob.cit. p. 290. 
quatrocentos presos políticos apenas provenientes da repressão ao movimento de 1935.46

Preso sem acusação ou processo no momento em que estourava a revolta paulista, Heitor Ferreira Lima afirma que estaria há menos de uma semana nas dependências da Casa de Detenção da Capital Federal quando surgiram rumores de que uma leva de presos seguiria para a Colônia Correcional de Dois Rios. Conta que a notícia entreouvida "parecia verdadeira, transformando o ambiente e as fisionomias. A tranquilidade e quase alegria antes reinante transformava-se em preocupação, com as fisionomias carregadas",47 é explicada pelo autor por dois motivos. O primeiro se refere ao fato de que estavam todos “detidos às ordens do chefe de polícia', sem culpa formada nem processo instaurado", podendo serem postos em liberdade a qualquer momento. Porém, sendo enviados ao presídio da Ilha Grande, esse panorama mudava, a possibilidade de libertação ficava cada vez mais distante e aumentava a perspectiva de que a prisão seria prolongada. Lima, preso em 1932, foi libertado apenas em 1934.

Preocupação parecida demonstra Basbaum que afirma que ele e seus companheiros não sabiam quanto tempo iriam passar em Ilha Grande pois não eram condenados e sequer tinham processo. "Isolados do mundo, poderíamos ficar ali anos e anos, ou, quem sabe, até o fim da vida.” Reflete o autor, afirmando que na Casa de Detenção pelo menos o Socorro Vermelho teria alguma possibilidade de encontrar-lhes um advogado, mas o isolamento da prisão insular tornaria isso muito difícil, além do fato de que naquele momento Getúlio Vargas teria decretado estado de sítio, por conta da Revolução Constitucionalista em São Paulo, o que suspendia uma série de direitos civis. Apesar disso, Basbaum afirma que eles tinham esperanças de que fossem libertados assim que o movimento paulista chegasse ao fim. ${ }^{48}$

O segundo motivo para Lima e seus companheiros mostrarem-se preocupados tinha a ver com o receio acerca do imaginário sobre a ilha prisional, permeado pelo trabalho coercitivo, violência e convivência com criminosos. Nas palavras do autor:

“A Colônia Correcional era o presídio mais abjeto que havia, para onde mandavam a escória da malandragem, [...] gente sem o menor sentimento humano nem escrúpulo ou

\footnotetext{
${ }^{6} 6$ SEPÚLVEDA, Myrian. Os porões da República: a barbárie nas prisões da Ilha Grande: 1894-1945. Rio de Janeiro: Garamond, 2009.

${ }^{47}$ LIMA, Heitor Ferreira. Ob. cit., p. 163.

48 BASBAUM, Leôncio. Ob.cit. p. 133, 134..
} 
qualquer consideração pelos outros e ainda com trabalhos forçados e sujeitos a constantes surras com vara de marmelo".49

Na Ilha Grande, “os recém-chegados são os primeiros a saírem em fila, escoltados, para o almoço”, porém o autor reclama que a refeição servida era precária: "feijão e arroz duros e sem gosto, acompanhados de pedaço de carne-seca, com manchas arroxeadas pela podridão e pequeno pão, também duro, servido em pratos de folhas de Flandres e colher meio enferrujada”. Após o almoço, esses novos presos teriam um momento para ficar no pátio do presídio, ocasião em que “os presos comuns compram, a dinheiro ou em troca de cigarros, esteiras, cobertores e outros objetos de uso [pessoal]”, enquanto que os presos políticos acabavam por receber essas coisas 'gratuitamente' dos presos políticos que lá já se encontravam, por camaradagem.

Faz-se necessário notar que os autores sempre fazem referência ao seu grupo de presos políticos com qualidades positivas, como a solidariedade com a qual agiam entre si, no caso mencionado acima. De forma inversa, sempre qualificam de forma negativa os presos comuns, afinal os consideravam como lumpemproletários, a "escória da malandragem”, "gente sem o menor sentimento humano nem escrúpulo ou qualquer consideração pelos outros" como define Lima.

Este autor conta também que o primeiro dia em Ilha Grande teria sido marcado pelo que ele ouviu um preso chamar de "escrache", que não passava de um processo prisional de despersonalização, que buscava impor controle sobre os indivíduos encarcerados desde o primeiro momento em que se encontravam na prisão. Os presos novatos eram chamados para formarem filas em frente à Diretoria, onde passavam por um processo de "identificação e rapidíssimo exame médico, consistente em simples olhar da cabeça aos pés”, depois recebiam um papel com um número escrito, pelo qual deveriam responder dali em diante, e roupas novas - "calça e blusa de gola em pé, com listras azuis horizontais: era a zebra”.50

Porém, Lima afirma que os presos políticos não recebiam os mesmos tratamentos que os presos comuns - que frequentemente eram espancados e obrigados a realizar os serviços gerais do presídio. Os presos políticos tinham, como também relatou Bezerra, mais liberdade de ir e vir nos entornos do presídio da Ilha

\footnotetext{
49 LIMA, Heitor Ferreira. Ob.cit. p. 163, 164.
}

5o LIMA, Heitor Ferreira. Ob.cit. p. 165, 166. 
Grande, podendo passear na praia, tomar banho de mar e, alguns, foram autorizados a residir na ilha com suas esposas e filhos.

Já Basbaum conta que, ao chegar na Ilha Grande, o seu grupo de presos foi recolhido ao presídio que "se constituía de uma série de galpões de alvenaria e telha, emendados uns aos outros, formando um quadrado, sem janelas por fora e dando saída para um pátio interno que teria o tamanho de metade de um campo de futebol”. $\mathrm{O}$ galpão que Basbaum e seus companheiros teriam ocupado "era rodeado internamente por um estrado de madeira”, no qual eles dormiriam em colchões infestados de percevejos e onde já havia alguns presos comuns.

Logo no dia seguinte de sua chegada, os presos políticos novatos ali teriam sido divididos para as turmas de trabalho da lenha e da viga.

\footnotetext{
"O trabalho da turma da lenha era mais suave: tinha de subir o morro e apanhar a lenha cortada no dia anterior por alguns presos e trazê-la para baixo, para a cozinha. A lenha era carregada nos ombros, em feixes, e havia um número mínimo de achas que cada um devia carregar, pudesse ou não." ${ }^{11}$
}

Basbaum fora incorporado à turma da viga, onde a tarefa era "subir o morro e 'encaminhar' a viga para baixo. Essa viga era um tronco de árvore derrubada na véspera, por um grupo de presos comuns.” O trabalho se constituiria como “extremamente perigoso" pois “já havia vários casos de morte entre presidiários que se encontravam no caminho da viga em sua corrida vertiginosa para baixo, dentro de uma trilha que as próprias vigas haviam cavado”. Sua função nessa turma era portar um machado, com o qual deveria aparar as pontas de galhos que impediam a descida das vigas - o que provocava brincadeira por parte dos presos políticos que conheciam Basbaum pelo seu nome de guerra, que era justamente Machado.

Um tempo depois, Basbaum foi enviado para conversar com o médico do presídio, o doutor Hermínio Ouropretano Sardinha, descrito pelo autor como "um homenzinho magro, que gostava de bancar o homem mau, mas se percebia que apenas se vingava da humanidade que o havia empurrado para ser médico [...] de um bando de vagabundos". Para provar ser médico formado, o dr. Sardinha exigiu que Basbaum lhe desse alguns nomes de professores de medicina e, assim, o preso político foi

${ }^{51}$ BASBAUM, Leôncio. Ob.cit. p. 132 e 135. 
transferido da turma de vigas para o hospital que ficava perto da praia, distante cerca de duzentos metros do presídio e se constituía de uma casa com poucos cômodos, alguns leitos, um escritório consultório, mas onde "o médico nunca aparecia". "Na ocasião [da transferência de Basbaum] havia apenas um doente: um homem tuberculoso que estava apenas esperando a hora de morrer pois não havia tratamento para ele”. Enquanto trabalhou no hospital, Basbaum atendeu presos com perturbações intestinais e doenças venéreas, sendo estas "tratadas como sífilis (não havia ainda antibióticos nem sulfas) com injeções de 914, o grande remédio da moda” e muitos casos de avitaminose, "para os quais não tínhamos tratamento, a não ser pomadas inócuas, quando se revelavam por úlceras nas pernas". ${ }^{2}$

\section{Conclusão}

Neste artigo, analisamos quatro obras autobiográficas e, nelas, traçamos um recorte analítico que permite vislumbrar as trajetórias de encarceramento dentro das trajetórias de vida dos autores que foram presos políticos durante a Era Vargas. Buscamos com isso compreender a narrativa sobre suas passagens pelas Casas de Detenção do Rio de Janeiro, de Fortaleza e de Recife, mas também suas estadias nas ilhas Grande e Fernando de Noronha e no cárcere em movimento nos quais se constituíram os navios que os transportaram entre prisões continentais e insulares.

Em O mundo da violência, Elizabeth Cancelli argumenta que na era Vargas, "o sistema penitenciário assumia gradualmente, depois de 1930, seu papel radicalizador: colocar sob a exclusão do mundo dos vivos certas categorias da população”. ${ }^{33}$ Apesar dessa exclusão imposta pelo governo ditatorial de Getúlio Vargas, as categorias excluídas e legadas aos espaços do sistema penitenciário não eram homogêneas, nem se mantinham estáveis dentro das prisões. Longe de serem objetos inertes dentro de uma ordem repressiva que os imobilizava por completo, os presos comunistas participaram do processo de elaboração e reelaboração dos significados acerca da experiência prisional e do imaginário sobre as prisões.

Nos relatos podemos perceber que, apesar da situação de coerção e repressão estatal em que se encontravam, os presos conseguiam desenvolver maneiras de

$5^{2}$ BASBAUM, Leôncio. Ob.cit. p. 135, 136.

53 CANCELLI, Elizabeth. O mundo da violência: a polícia na Era Vargas. Brasília: Editora Universidade de Brasília, 1993. p. 180. 
negociar e edificar espaços de liberdade e militância. Encontramos narrativas de um cotidiano permeado de agência em busca da continuidade da militância, apesar da vigilância e dos limites impostos pelo espaço da prisão e pelo regime autoritário vivido durante a Era Vargas. As relações dos autores, quando presos políticos, com as diferentes categorias de pessoas que viviam o espaço prisional nos mostram diferentes nuances e matizes na maneira de lidar com as negociações necessárias na busca por aumentar as margens de liberdade. Por vezes, essas relações são conflituosas e permeadas de tensões, como no embate entre presos e soldados dentro do navio que levava Bezerra para Fernando de Noronha e na forma desconfiada como os comunistas lidavam com os presos comuns ou mesmo podia vir a se tornar amigável, como quando o autor desenvolve uma amizade com o guarda-cárcere, que se converte em militante comunista.

Por fim, podemos concluir que não há uma completa interrupção da maneira como os autores já viviam a militância quando em liberdade, mas há transformação e adaptação às possibilidades dentro da prisão. A despeito das intenções biográficas e escolhas narrativas feitas por cada autor, suas memórias da trajetória de prisão descortinam um cotidiano prisional em que os presos políticos se deparam com a coerção, violência, controle e estranhamento quanto aos indivíduos que convivem.

$\diamond \diamond \diamond \diamond \diamond \diamond \diamond \diamond \diamond \diamond$

\section{Referências Bibliográficas}

AGUIRRE, Carlos. The Criminals of Lima and their Worlds: The Prison Experience, 1850- 1935. Durham, Duke University Press, 2005.

ARTIÈRES, Philippe. Les Livres de Vies Coupables: autobiographies de criminels (1896-1909). Paris, Éditions Albin Michel, 2000.

BARATA, Agildo. Vida de um revolucionário. São Paulo, Alfa-Ômega, 1978.

BASBAUM, Leôncio. Uma vida em seis tempos (memórias). São Paulo, Alfa-Ômega, 1976.

BEZERRA, Gregório. Memórias. São Paulo, Boitempo, 2011.

CAIMARI, Lila. "Remembering freedom: life as seen from the prison cell", in: AGUIRRE, C.; SALVATORE, R.; GILBERT M., Joseph. Crime and Punishment in Latin America. Law and society since late colonial times. Durham y Londres, Duke University Press, 2001.

CANCELLI, Elizabeth. O mundo da violência: a polícia na Era Vargas. Brasília, Editora Universidade de Brasília, 1993. 
CHAZKEL, Amy. "Uma perigosíssima lição: A Casa de Detenção do Rio de Janeiro na Primeira República”. Em: MAIA, C., NETO, F.S., COSTA, M., BRETAS, M. História das Prisões no Brasil. Rio de Janeiro, 2009, vol. 2.

COSTA, Marcos Paulo Pedrosa.

-O caos ressurgirá da ordem: Fernando de Noronha e a reforma prisional no Império. São Paulo, IBCCRIM, 2009.

-"Fernando e o mundo - o Presídio de Fernando de Noronha no século XIX”. Em: BRETAS, Marcos, COSTA, Marcos, MAIA, Clarissa, NETO, Flávio de Sá. História das prisões no Brasil. Rio de Janeiro, Rocco, 2009. p. 135 - 167.

FILHO, Porfírio de Lima. No tempo dos Látegos e dos Grilhões: memória sobre a Cadeia Pública de Fortaleza (1931). Fortaleza, Arquivo Público do Estado do Ceará, 2013.

LIMA, Heitor Ferreira. Caminhos Percorridos (memórias de militância). São Paulo, Brasiliense e AEL, 1982.

LINEBAUGH, Peter; REDIKER, Marcus Buford. A hidra de muitas cabeças: marinheiros, escravos, plebeus e a história oculta do Atlântico revolucionário. São Paulo, Companhia das Letras, 2008.

MAGALHÃES, Mário. Marighella, o guerrilheiro que incendiou o mundo. São Paulo, Cia das Letras, 2012.

NETO, Flávio de Sá C.A. "Da cadeia à Detenção: reforma prisional no Recife em meados do século XIX”. Em: MAIA, C., NETO, F.S., COSTA, M., BRETAS, M. História das Prisões no Brasil. Rio de Janeiro, 2009, vol. 2.

MAIA, C. A. "Casa de Detenção do Recife: controle e conflitos (1855-1915)". Em: MAIA, C., NETO, F.S., COSTA, M., BRETAS, M. História das Prisões no Brasil. Rio de Janeiro, 2009, vol. 2, p. 112 - 115.

RODRIGUES, Jaime. "Escravos, senhores e vida marítima no Atlântico: Portugal, África e América Portuguesa, c.1760 - c.1875”. Almanack, Guarulhos, n. 5, p. 145-177, 2013.

SCHARCZ, Lilia, STARLING, Heloísa. Brasil: uma biografia. São Paulo, Cia das Letras, 2015.

SEPÚLVEDA, Myrian.

-Os porões da República: a barbárie nas prisões da Ilha Grande: 1894-1945. Rio de Janeiro, Garamond, 2009.

-“O encontro da militância com a vadiagem nas prisões da Ilha Grande”. Topoi , Rio de Janeiro, v. 18, n. 35, p. 356-380, maio/agosto de 2017.

VAN DER LINDEM, Marcel. "O Conceito Marxiano de Proletariado: uma crítica”. Em: Sociología \& Antropologia, Rio de Janeiro, v.o6.01: 87-110, 2016.

Cita sugerida: Sobrinho, Priscila. (2019) “¿Cruzando fronteras? La prensa y el primer cruce a nado del Río de la Plata, Uruguay-Argentina, 1923”, Claves. Revista de Historia, Vol. 5, No 8, ISSN 23936584, pp. 235-26o. DOI: http://dx.doi.org/10.25032/crh.v5i8.10 